\title{
Study of the Action of Smoke on Alcohol Dehydrogenase, Lactic Dehydrogenase and Malate Dehydrogenase Enzymes*
}

\author{
by Mirella Neri and Nicola Carugno \\ Monopoli di Stato, Servizio Ricerche Chimiche e Tecnologiche, \\ Rome, Italy
}

\section{SUMMARY}

The aim of this study is to acquire better knowledge of the action of the whole smoke and the vapour phase on alcohol dehydrogenase (ADH), lactic dehydrogenase $(\mathrm{LDH})$, and malate dehydrogenase $(\mathrm{MDH})$.

The method developed provides that smoke comes into direct contact with the various enzymatic solutions without any preventive extraction, as in previous methods. It is based on the determination of the degree of inhibition of sulfhydryl reagent groups of enzyme by smoke.

Additionally, the efficiency of cigarette filters for the reduction of this inhibition was evaluated.

The purpose of this study also included the examination of the protective effect of thiol groups of enzymes against the inhibitory action of smoke.

The results obtained show a high reactivity of smoke with sulfhydrylic groups of the enzymes examined. The effect of this reactivity is different for the three enzymes considered and dependent upon the role that sulfhydryl reagent groups had in the enzymatic activity. In particular, it was found that alcohol dehydrogenase, which needs all its sulfhydryl groups for its own activity, undergoes a strong inhibition due to smoke, while lactic dehydrogenase shows a negligible inhibition.

The tests made have also shown the protective action of thiol on the inhibited enzymes.

\section{ZUSAMMENFASSUNG}

Zweck der vorliegenden Untersuchung war es, besser kennenzulernen, wie Gesamtrauch und Gasphase auf folgende drei Enzyme wirken: Alkoholdehydrogenase $(\mathrm{ADH})$, Lactatdehydrogenase (LDH) und Malatdehydrogenase $(\mathrm{MDH})$.

\footnotetext{
* Presented at the 7 th Intemational Tobaceo Scientific Congress (Coresta) held in Manila, The Philippines, in 1980.

Received: 28ih October 1981 - accepted: 23rd Decernber 1982.
}

Die Untersuchungen basierten auf der Bestimmung der Hemmung der Sulfhydrylgruppen der Enzyme durch Rauch und waren methodisch so angelegt, daß der Rauch ohne die bisher übliche vorherige Extraktion direkt mit den verschiedenen Enzymlösungen in Verbindung kam.

Darüber hinaus wurde untersucht, inwieweit Zigarettenfilter die Enzymhemmung vermindern können.

Auch wurde zu ermitteln versucht, in welchem Maße 'Thiolgruppen in den Enzymen gegen die Hemmwirkung des Rauches schützen.

Die Ergebnisse zeigen eine hohe Reaktivität des Rauches mit den Sulfhydrylgruppen der Enzyme. Die Intensität der Reaktion war bei den drei Enzymen unterschiedlich stark und abhängig von der Rolle, die die Sulfhydrylgruppen bei der jeweiligen enzymatischen Aktivität spielen. Im einzelnen zeigte sich, daß die Alkoholdehydrogenase, die alle ihre Sulfhydrylgruppen zur Entfaltung ihrer Wirksamkeit braucht, durch Rauch stark gehemmt wird und daß die Hemmung der Lactatdehydrogenase gering ist.

Die Untersuchungen zeigten auch, daß Thiole eine schützende Wirkung auf die gehemmten Enzyme ausüben.

\section{RESUME}

Le but de cette étude était d'acquérir une meilleure connaissance de l'action de la fumée totale et de la phase gazeuse sur les trois enzymes suivants : dẻhydrogénase d'alcool $(\mathrm{ADH})$, déhydrogénase de lactate (LDH) et déhydrogénase de malate (MDH).

La méthode appliquée mettait directement en contact la fumée avec les différentes solutions enzymatiques sans recourir à l'extraction préalable habiruelle; elle se fondait sur la détermination du degré d'inhibition des groupes sulfhydriles des enzymes sous l'effet de la fumée.

Par ailleurs, on a essayé de déterminer dans quelle mesure le filtre de cigarettes diminue l'effet inhibiteur de la fumée. 


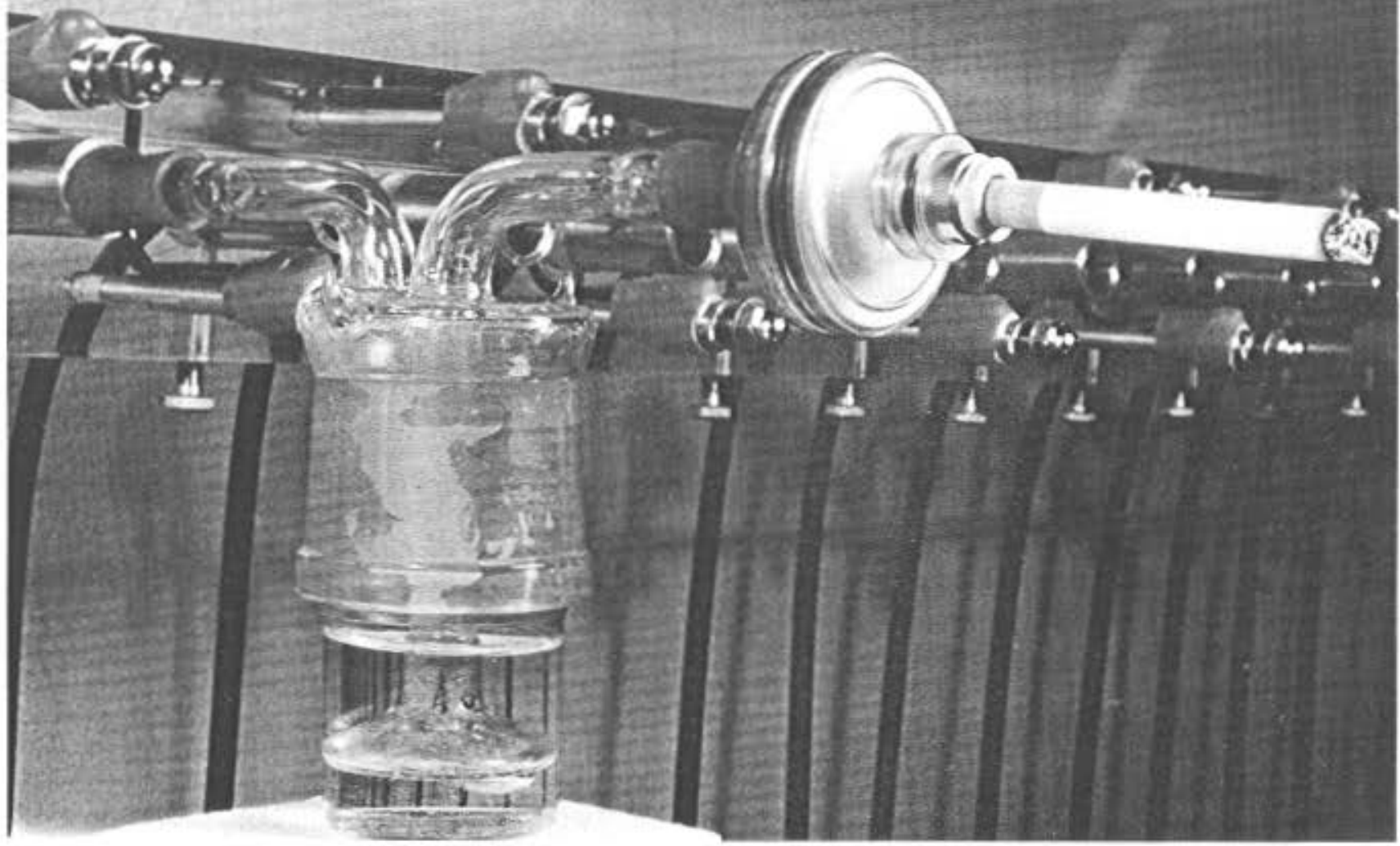

Figure 2. Whole smoke collection device.

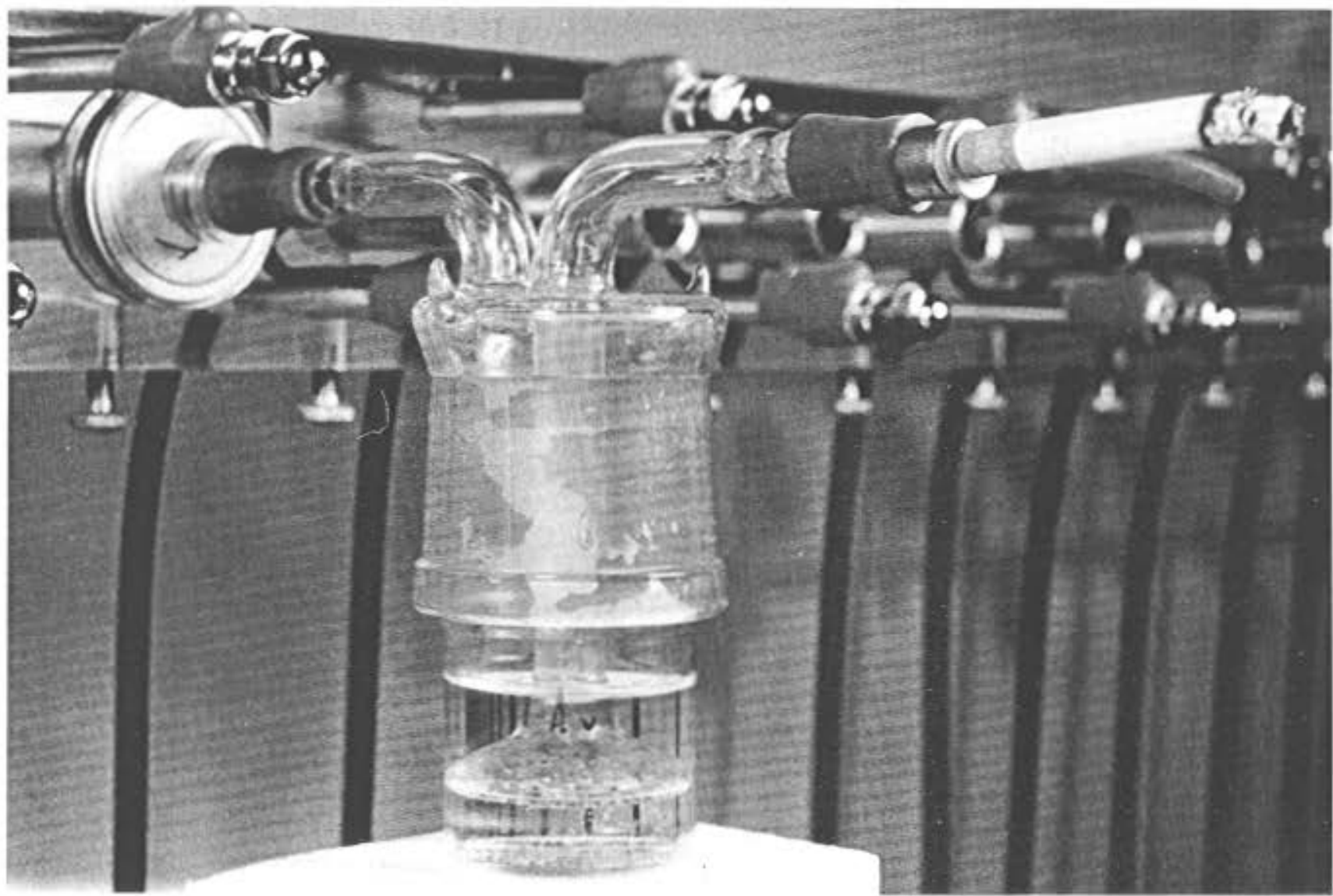


L'étude essaya également de déterminer dans quelle mesure les groupes thiols pouvaient protéger les enzymes contre l'effet inhibiteur de la fumée.

Les résultats obtenus ont fait apparaître une forte réactivité de la fumée sous l'action des groupes sulfhydriles des enzymes. L'intensité de la réaction varie selon les trois enzymes, compte tenu du rôle joué par les groupes sulfhydriles dans l'activité enzymatique considérée. Il est apparu en particulier que la déhydrogénase d'alcool ayant besoin de tous ses groupes sulfhydriles pour développer sa propre activité, est fortement inhibée par la fumée, tandis que la déhydrogénase lactique présente une inhibition négligeable.

Les tests ont également révélé que les thiols exercent un effet protecteur sur les enzymes inhibés.

\section{INTRODUCTION}

With the present work, we tried to acquire better knowledge of the action of the cigarette whole smoke and vapour phase on three enzymes: yeast alcohol dehydrogenase (YADH), lactic dehydrogenase (LDH), and malate dehydrogenase (MDH).

The subject was investigated by several authors $(1,2)$ in order to explain the mechanism of enzyme inhibition by smoke and to determine which substances are responsible for this inhibition. The choice of dehydrogenase as a test is supported by the fact that it is by now widely believed that some substances present in smoke inhibit the activity of sulfhydryl reactive enzymes. This method differs from the previous ones $(3,4,5,6)$ because it does not require extractions nor complicated preparations, but allows instead the smoke to come directly in contact with the various solutions containing enzymes.

With this study, we also wanted to examine what would be the inhibiting action on enzymes of both the whole smoke and the vapour phase, as well as to determine the efficacy of some filter types in reducing such inhibition.

Moreover, the protective action of a thiol (cysteine) was tested on enzymes when they come in contact with smoke.

\section{EXPERIMENTAL PART}

\section{Materials and Equipment}

Cysteine, YADH, LDH from pig muscle, MDH from pig heart, sodium pyruvate, sodium oxalacetate, nicotinamide adenine dinucleotide (NAD) and nicotinamide adenine dinucleotide reduced (NADH) were purchased from $\mathrm{BDH}$ Chemical Ltd.; $\mathrm{K}_{2} \mathrm{HPO}_{4}, \mathrm{Na}_{3} \mathrm{PO}_{4}$ and anhydrous ethanol were produced by Carlo Erba. Commercial cigarettes made of the same tobacco blend but with different filter types were smoked under standard ISO-CORESTA conditions $(35 \mathrm{ml}$ volume, 2 -second puff, 1 puff per minute (8-10)).
The vapour phase of the cigarettes was collected in a container that was placed between the smoking machine and the Cambridge filter (Figure 1). For the whole smoke analysis, the same container was directly connected with the cigarette, while the Cambridge filter was placed before the smoking machine (Figure 2). In both cases the container was dipped in ice in order to favour the absorption of smoke by the buffer solution.

Equipment: Beckman spectrophotometer (Model DB), Filtrona (Model 300) smoking machine, gas chromatograph with ionization flame detector (glass capillary columns, $120 \mathrm{~cm}$ in length; inside diameter, $0.3 \mathrm{~mm}$; graphitized and covered with $50 \mathrm{HB} 2000$ ).

\section{Determination of Enzyme Activities}

The activity of alcohol dehydrogenase (ADH) was determined by mixing the enzyme $(0.02 \%)$ with anhydrous alcohol and nicotinamide adenine dinucleotide $(0.04 \%)$, both in a phosphate buffer $(0.02 \mathrm{M})$ of pH 8.80. The change in absorbance of NAD reduced/ oxidized at $340 \mathrm{~nm}$ was used to evaluate the enzyme activity. The ratio of the formed NADH to the initial $\mathrm{NAD}$ read at $340 \mathrm{~nm}$ gives the extent of the dehydrogenases using the NAD as coenzyme:

$$
\begin{gathered}
\mathrm{C}_{2} \mathrm{H}_{3} \mathrm{OH}+\mathrm{NAD}+\mathrm{YADH} \rightarrow \\
\mathrm{CH}_{3} \mathrm{CHO}+\mathrm{NADH}+\mathrm{H}^{+} .
\end{gathered}
$$

The activity of lactic dehydrogenase (LDH) was determined by mixing the enzyme with NADH $(0.04 \%)$ and sodium pyruvate $(0.05 \%)$ in a phosphate buffer solution $(0.02 \mathrm{M})$ of $\mathrm{pH} 7.2$ and by following the decrease in absorption at $340 \mathrm{~nm}$ due to the coenzyme oxidation.

The same method was applied for the measurement of malate dehydrogenase (MDH) activity [sodium oxalacetate $(0.08 \%)$, NADH $(0.04 \%)$ in phosphate buffer $(0.02 \mathrm{M})$ of $\mathrm{pH} 8.80]$.

\section{RESULTS AND DISCUSSION}

Fig. 3 shows the reduction in activity of YADH due to the vapour phase (VP) of 10 cigarettes made both without and with different types of filters. In particular, curve a of Figure 3A shows how the YADH activity is reduced to $68 \%$ of that of plain control cigarettes and in cigarettes with cellulose acetate and cellulose filters, while YADH activity is reduced only to $84 \%$ in cigarettes with silica and carbon (or charcoal) filters (curve a in Figure 3B). In both cases, if cysteine is added to the enzymatic solution, thiol protects the enzyme completely, as is shown in curve b.

When the vapour phase of 20 cigarettes is tested, the enzyme activity decreases to $20 \%$ both for cigarettes without filter and with cellulose and cellulose acetate filter, and to $25 \%$ for cigarettes with silica or carbon filter (curve $a_{1}$ in Figs. $3 A$ and $3 B$ ). Even under these 
Figure 3. Inhibition of yeast alcohol dehydrogenase (YADH) by the vapour phase of cigarettes manufactured with the same blend but different fliters.

A
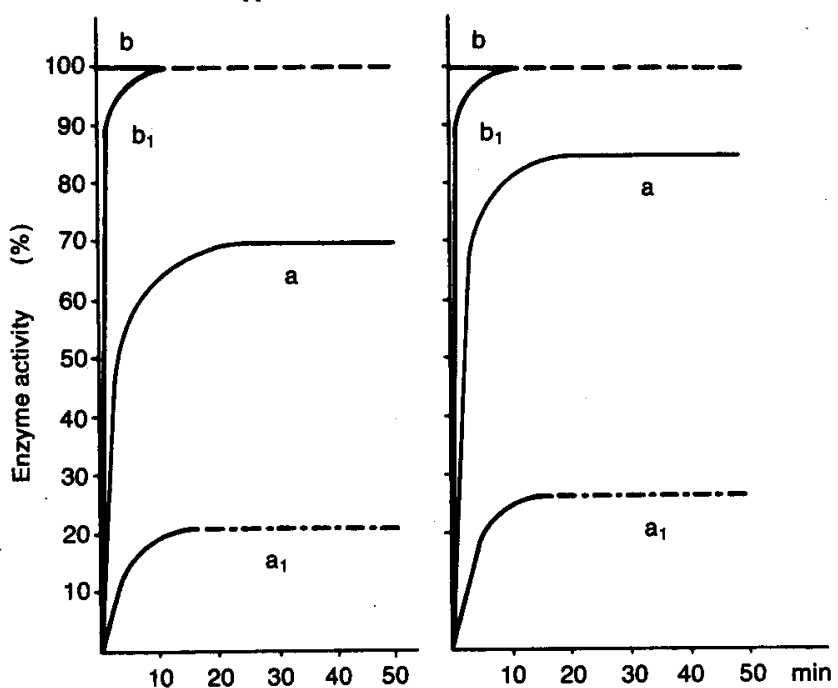

A/a: activity of YADH with the vapour phase of 10 each of the following three cigarette types: plain, cellulose acetate filter and cellulose filter.

b: as in a, but with cysteine added.

$a_{1}$ : activity of YADH with the vapour phase of 20 each of the following three cigarette types: plain, cellulose acetate filter and cellulose filter.

$b_{1}$ : as in $a_{1}$, but with cysteine added.

B/a: activity of YADH with the vapour phase of 10 cigarettes each with filters of silica or activated carbon cellulose acetate.

b: as in a, but with cysteine added.

$a_{1}$ : activity of YADH with the vapour phase of 20 cigarettes each with filters of silica or activated carbon cellulose acetate.

$b_{1}$ : as in $a_{1}$, but with cysteine added.

A

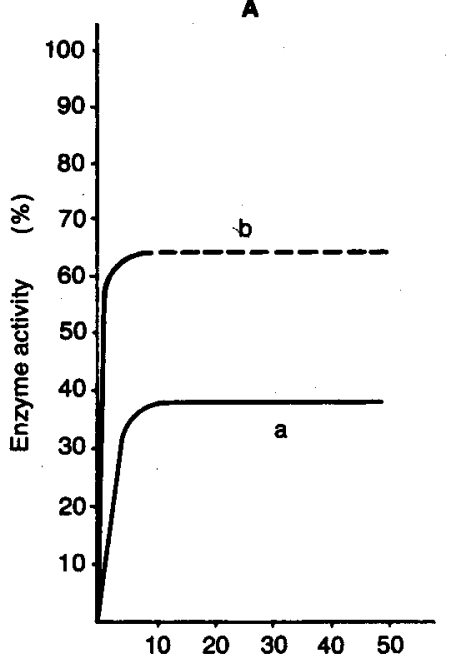

C

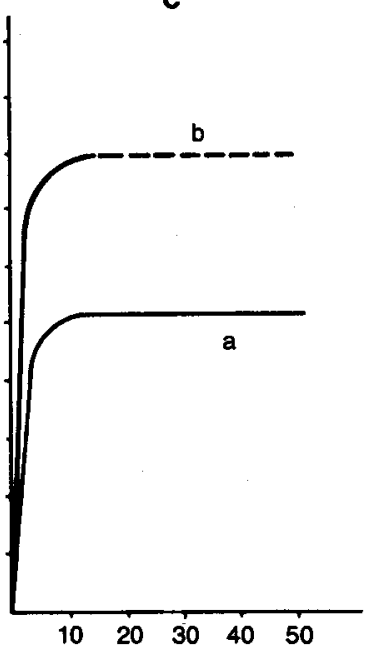

Figure 4. Inhibition of yeast alcohol dehydrogenase (YADH) by the whole smoke of plain clgarettes.

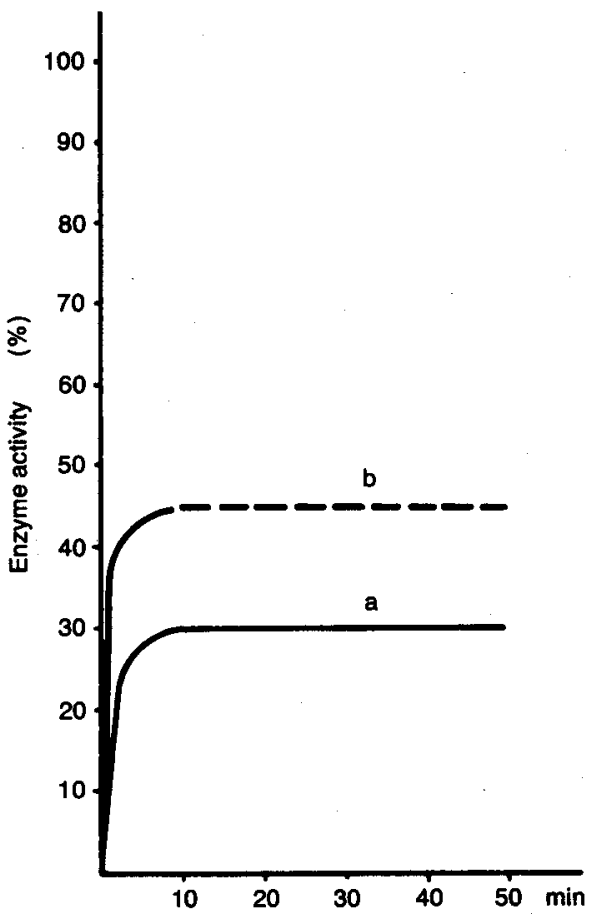

a: residual activity of YADH with the whole smoke of 5 plain cigarettes.

b: as in a, but with cysteine added.

Figure 5. Inhibition of yeast alcohol dehydrogenase (YADH) by the whole smoke of clgarettes manufactured with the same blend but different filters.
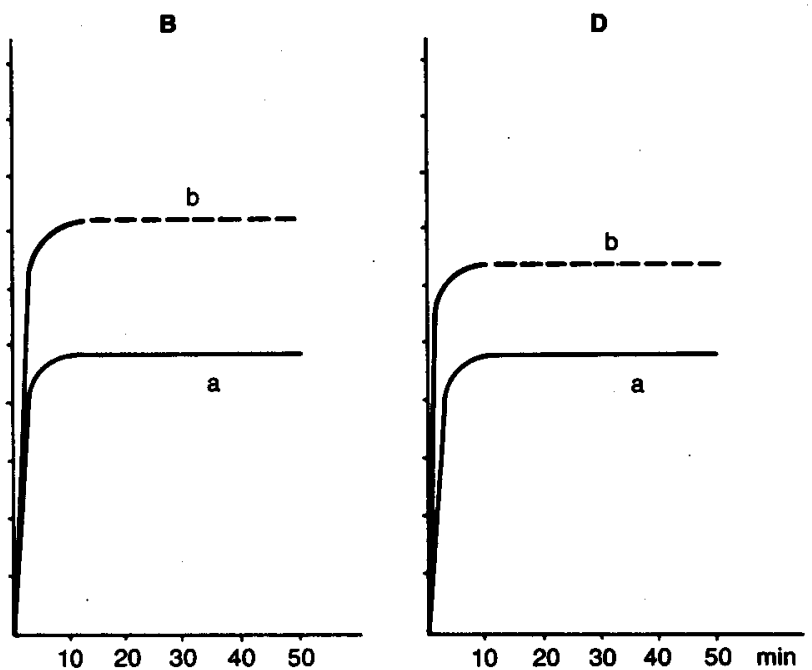

A/a: residual activity of YADH with the whole smoke of 5 cellulose acetate filter cigarettes.

b: as in a, but with cysteine added.

C/a: residual activity of YADH with the whole smoke of 5 activated carbon cellulose acetate filter cigarettes.

b: as in a, but with cysteine added.

B/a: residual activity of YADH with the whole smoke of 5 cellulose filter cigarettes.

$b$ : as in $a$, but with cysteine added.

D/a: residual activity of YADH with the whole smoke of 5 silica cellulose acetate filter cigarettes.

b: as in a, but with cysteine added. 
conditions, with the addition of cysteine YADH recovers - even if less quickly - its complete activity. It is evident that the vapour phase of cigarette smoke contains substances that by reacting with the sulfhydryl groups of YADH inhibit the enzyme. The inhibition percentage is a function of the smoked cigarettes. Cysteine, with its free sulfhydryl groups, is able to react with inhibiting substances which are present in the smoke vapour phase, thus protecting the enzyme.

Curve a of Figure 4 shows how the whole smoke of five plain cigarettes reduces the enzyme activity to $30 \%$, while curve $b$ shows the course of the enzymatic activity when cysteine is added.

The curves a of Figure 5 show the percentage of the enzyme activity as a function of the various filters employed. It can be noticed that, for the whole smoke, unlike the vapour phase, cellulose shows a higher filtering power compared to that of cellulose acetate. The curves $b$ in each graph show the residual activity of YADH with the whole smoke of five cigarettes with cysteine added. The minimum quantity of cysteine to be added to the reacting mixture in order to obtain the maximum protection was considered. Such minimum quantity of thiol under the experimental conditions of that test appeared to be $15 \mathrm{mg}$ per 5 cigarettes.

Lactic dehydrogenase shows a different course from yeast alcohol dehydrogenase, as the enzyme in contact with the vapour phase both of 10 and 20 cigarettes does not suffer a decrease in activity, while a small reduction appears with whole smoke. This can be explained by assuming that for lactic dehydrogenase the inhibition due to sulfhydryl-reacting compounds is very slow, so

Figure 6. Inhibition of malate dehydrogenase (MDH)

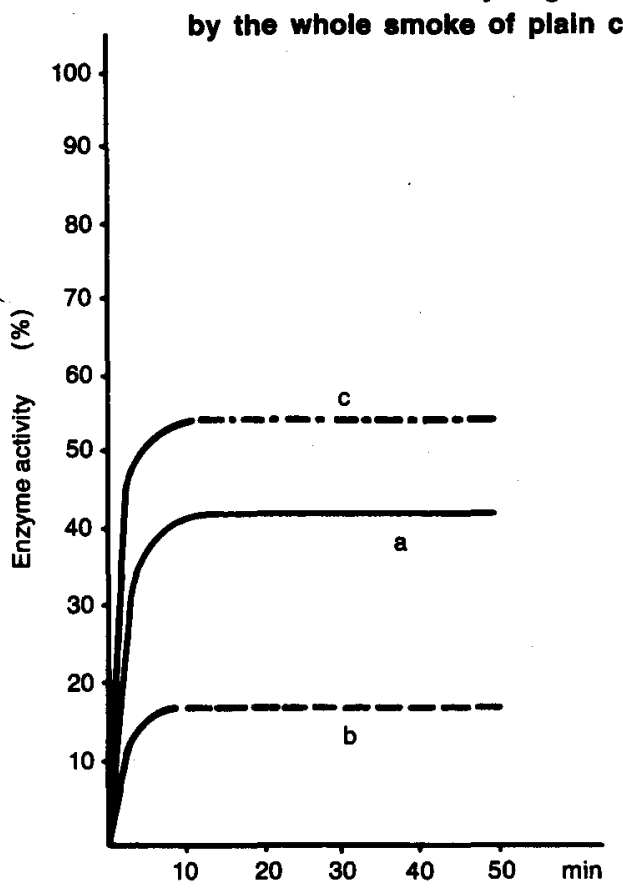

a: residual activity of $\mathrm{MDH}$ with the whole smoke of 5 plain cigarettes. b: residual activity of MDH with the whole smoke of 10 plain cigarettes. c: as in b, but with cysteine added. much so that $p$-chloromercuribenzoate, a substance that is normally used to provide evidence of sulfhydryl groups, inhibits the enzyme only after one hour.

In fact, of the 18 sulfhydryl groups that are present in the molecule, only two are active spots, i.e. essential spots for the activity of the enzyme, and in addition they are very well protected by the tetrahedral structure of the molecule. In yeast alcohol dehydrogenase, instead, all 32 sulfhydryl groups are essential to the enzymatic activity. The third enzyme examined, the malate dehydrogenase, also displays inhibition from cigarette smoke, even if to a lesser extent than YADH. For this enzyme, it was expedient to consider only the effect due to the whole smoke, as the vapour phase has little influence. Curve a in Figure 6 shows the residual enzymatic activity after the reaction of the buffer malate dehydrogenase solution with the whole smoke of five plain cigarettes, while curve $b$ covers the residual activity due to the whole smoke of ten cigarettes. By adding cysteine, we obtain curve $c$, where a slight protection of thiol can be noticed. Figure 7 shows the course of the enzymatic activity of the buffer malate dehydrogenase solution after the passage of the smoke of cigarettes made with different types of filters.

Figures $8 \mathrm{~A}$ and $8 \mathrm{~B}$ compare the gas chromatograms (7) of the vapour phase from 64 cigarettes of a commercial brand, after its passage through $25 \mathrm{ml}$ of a phosphate buffer solution $(0.02 \mathrm{M})$ of $\mathrm{pH} 8.80$ and through the same solution but with yeast alcohol dehydrogenase added. The gas chromatograms of the gas phase absorbed first in a buffer solution, and then in a buffer solution with the enzymes examined, are highly repeating and show a marked decrease of peaks 1 and 4 (acetaldehyde and acetone respectively) because such enzymes have reactive sulfhydryl groups and the compounds reduced are carbonylic ones. The thesis (confirmed by the authors indicated under references) supports the view that these compounds bind themselves steadily to the enzyme, as the free sulfhydryl groups are changed into a disulfide group or into a thiazolidine ring.

The gas chromatograms of the vapour phase relating to the lactic dehydrogenase and malate dehydrogenase enzymes do not differ from those shown for yeast alcohol dehydrogenase, while the variation in the enzymatic activity, as previously indicated, differs consistently among the three enzymes, as this difference is due to the number of sulfhydryl groups that are present in the molecule and to the percentage of these sulfhydryl groups that function as active spots.

For whole smoke, detection of the substances or of the factors that are responsible for the reduction of the enzymatic activity is certainly more complex. The inhibitions due to the denaturation of proteins, to the deactivation of cofactors such as nicotinamide adenine dinucleotide, and to reactions that can take place with the substrate, must be taken into account. This is the case, for instance, with the yeast alcohol dehydrogenase inhibition by hydroxylamine as the latter is competitive with alcohol. Also, the possibility should be considered 
Figure 8. Gas chromatograms of the vapour phase from 64 cigarettes, after its passage through $25 \mathrm{ml}$ phosphate butfer solution (0.02 M) of pH 8.80 .

\section{A: without YADH}

B: with YADH

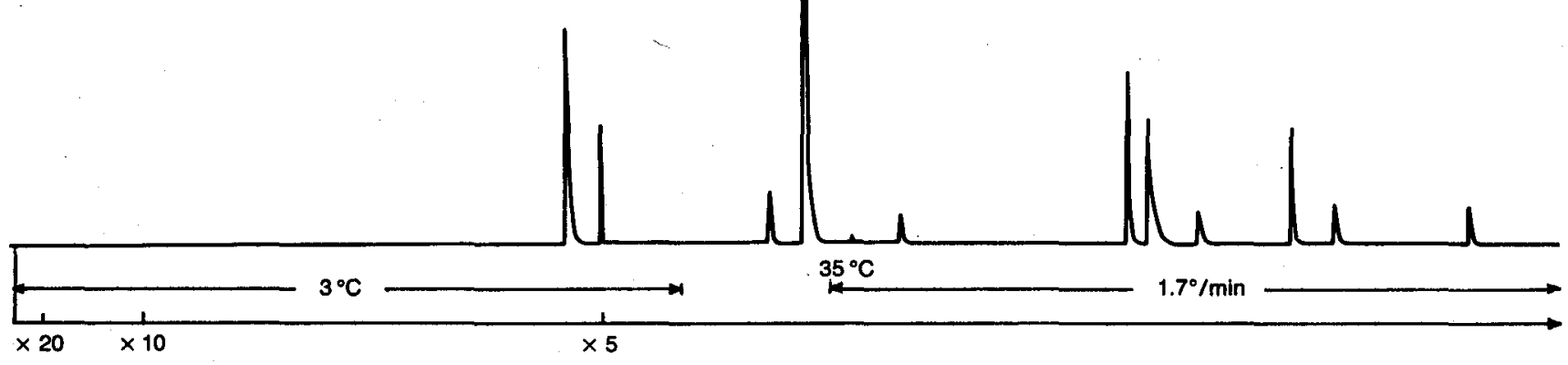


Figure 7. Inhibition of maiate dehydrogenase (MDH) by the whole smoke of cigarettes manufactured with the same blend but different filters.
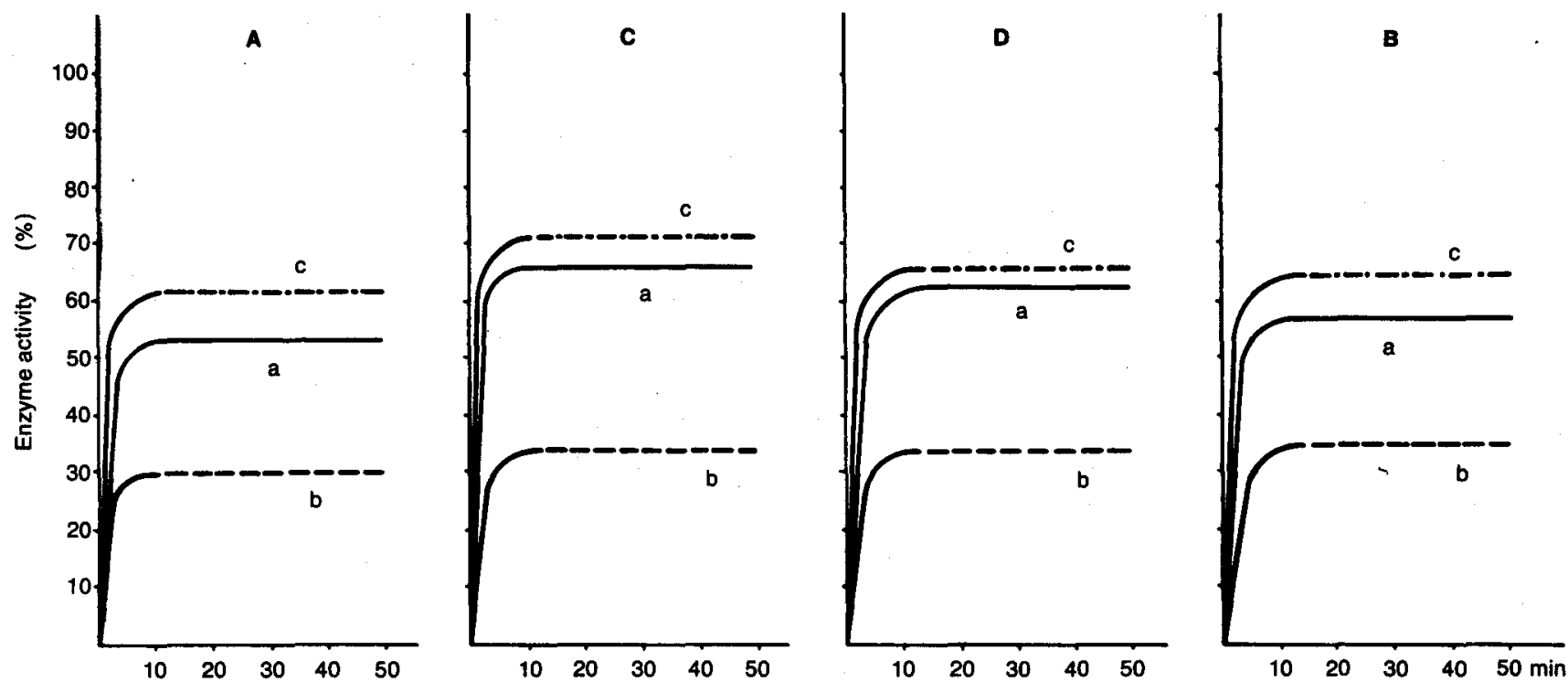

A/a: residual activity of $\mathrm{MDH}$ with the whole smoke of 5 cellulose acetate filter cigarettes.

b: residual activity of MDH with the whole smoke of 10 cellulose acetate filter cigarettes.

c: as in b, but with cysteine added.

C/a: residual activity of MDH with the whole smoke of 5 silica cellulose acetate filter cigarettes.

b: residual activity of $\mathrm{MDH}$ with the whole smoke of 10 silica cellulose acetate filter cigarettes.

c: as in b, but with cysteine added.

D/a: residual activity of MDH with the whole smoke of 5 activated carbon cellulose acetate filter cigarettes

b: residual activity of MDH with the whole smoke of 10 activated carbon cellulose acetate filter cigarettes.

c: as in b, but with cysteine added.

B/a: residual activity of MDH with the whole smoke of 5 cellulose filter cigarettes.

b: residual activity of MDH with the whole smoke of 10 cellulose filter cigarettes.

c: as in b, but with cysteine added.

that pyridine may substitute for the nicotinamide adenine dinucleotide ring, thereby involving a competitive reaction.

\section{REFERENCES}

1. Sato, T., T. Suzuki and T. Fukuyama: Cigarette smoke, Mode of adhesion and haemolyzing and SH-inhibiting factors; Br. J. Cancer 16 (1962) 7-15.

2. Braven, J., G. J. Bonker, M. L. Fenner and B. L. Tonge: The mechanism of carcinogenesis by tobacco smoke, Some experimental observations and a hypothesis; Br. J. Cancer 21 (1967) 623-633.

3. Benedict, R. C., and R. L. Stedman: Complexity of enzymatic inhibition by cigarette smoke; Experientia 24 (1968) 1205-1206.

4. Benedict, R. C., and R. L. Stedman: Composition studies on tobacco, XXXVII.: Inhibition of lactic, . alcohol and glucose-6-phosphate dehydrogenases by cigarette smoke and components thereof; Tobacco Science 13 (1969) 166-168.

5. Benedict, R. C., R. L. Stedman and R. L. James: Composition studies on tobacco, XLVI.: Attempts to modify selected biochemical properties of cigarette smoke by the use of specially treated filters; Beitr. Tabakforsch. 6 (1972) 189-193.
6. Lange, R.: Inhibiting effects of tobacco smoke on some crystalline enzymes; Science 134 (1961) 52-53.

7. Neri, M., N. Carugno and S. Rossi: Nouvelle méthode automatique pour la mesure de la réaction entre les composés de fumée de cigarette; Annales du Tabac 16 (1978) 89-95.

8. International Organization for Standardization (ISO): Tobacco and tobacco products - Atmospheres for conditioning and testing; International Standard No. 3402, 2nd edition, 1978.

9. International Organization for Standardization (ISO): Tobacco and tobacco products - Routine analytical cigarette-smoking machine - Definitions, standard conditions and auxiliary equipment; International Standard No. 3308, 1st edition, 1977.

10. Deutsches Institut für Normung (DIN): Maschinelles Abrauchen von Zigaretten und Bestimmung des Rauchkondensats; DIN 10240, April 1978.

\section{Authors' address:}

Monopoli di Stato,

Servizio Ricerche Chimiche e Tecnologiche,

Piazza Mastai 11, Rome, Italy. 